DOI https://doi.org/10.36059/978-966-397-158-2/103-118

\title{
DEMOCATIC CHANGES AND A HYBRID REGIME: A THEORETICAL ANALYSIS
}

\section{Dziubenko Yu. M.}

\section{INTRODUCTION}

Modern political processes are characterized by democratic transformations in most countries of the world, which in turn may be accompanied by certain problems. Particularly noteworthy is the problem of threats to democracy and the possibility of a hybrid regime. This problem has become more acute for our country when it comes to the possibility of a return of the political regime in Ukraine to authoritarianism. First of all, it is caused by a significant gap between the purpose, tasks and opportunities of reforming society, its democratization. Implementation and intensification of these threats will facilitate the transition from democratic transformation to reverse transit. Ukraine's political development after the recent events shows that considerable danger to the democratic path of development remains for our country even in the conditions of formally democratic and legitimate institutions.

The need to investigate the threats to democracy and the phenomenon of hybrid regimes is especially important in today's globalized environment, as democratic transit facilitates the country's place and role in the world community and will enable Ukraine to democratize further the society and build a European developed state.

\section{Hybrid political regime: a theoretical analysis}

Thus, among the most famous attempts to investigate the phenomenon of transitional forms of political regimes, we can distinguish the works of such foreign scientists as L. Diamond, G. O'Donnell, M. Ottawa, F. Zachary, T. Carothers, S. Levitsky and L. Wei, A. Shadler, F. Schmitter and others.

Therefore, the main task of this section is the theoretical analysis of the concept of hybrid mode. The hybrid political regime is separated into a separate category, based on the fact that with the existing features of the democratic regime in certain political systems there are still «defects» that characterize the political regime as a hybrid one. Based on this position, it is appropriate to consider the political regime with the term «democracy with 
adjectives $\gg{ }^{1}$ and the current regime is authoritarian, but characterized by the existence of separate democratic institutions, which distinguishes it from the classical forms of authoritarianism. It is not difficult to notice that under both positions the political regime is considered as «mixed», integrating both democratic and authoritarian characteristics. Let's trace the formation and evolution of these two traditions in modern political science.

Domestic scientific literature has been dominated by the view that Gorbachev's perestroika and its consequences should be clearly attributed to the democratization process. Initially, these processes were also considered abroad in the context of democratization ${ }^{2}$.

J.-F. Gage highlights the distinctive features of a hybrid political regime that allow it to be separated into a separate concept. In particular, the author identifies conceptual obstacles in the study of hybrid regimes - recurrence (hybrid regimes worldwide - the predominant form of political regimes), and this tendency is associated with the destruction of the bipolar system of international relations. Since that period, the ratio of the number of states with features of hybrid regimes has hardly changed in comparison with democracies and autocracies ${ }^{3}$ ), sustainability (only recently have studies begun to emerge that highlight the problems of stability and the dynamics of mixed political regimes). Thus, in the period from 1989 to 2007, L. Morlino analyzed the continuity and variability of political regimes. The author concluded that «at least 26 of these can be classified as «stable mixed regimes», i.e., which have been "partially free» for 15 years or longer, and 9 cases as «less continuous and mixed modes», which have existed 10 years without changes; however, of the 45 cases of mixed political regimes during this period, only 7 have carried out or transited democracy and 3 to authoritarianism» ${ }^{4}$ ), regional specifics $-\mathrm{N}$. Brown and K. Kauffman point out that one of the main problems facing researchers of democratic transitional processes is the possibility of separating the «extended transience» from stable political transition.

According to the opinion of A. Remizov, current theories explaining the causes and origins of mixed regimes are more suited to African and Eurasian countries (countries where mixed regimes emerged after the 1990s), and the

1 Collier D., Levitsky S. Democracy with Adjectives: Conceptual Innovation in Comparative Research. World Politics. 1997. Vol. 49. № 3. P. 430-451.

${ }^{2}$ O'Donnel G., Schmitter P. Transitions from authoritarian rule: prospects for democracy.. Baltimore, 1986. 208 p. transit

${ }^{3}$ Analytical briefs. Freedom House. URL: https://freedomhouse.org/report-types/nations-

${ }^{4}$ Ремізов А. Гібридний політичний режим: деякі проблеми концептуалізації. Освіта регіону. 2012. № 3. URL: http://social-science.com.ua/article/848. 
aim of this conception is according to J.-F. Gage, unreasonably, because it is in these regions that there are the most stable «mixed» forms of the regime. In addition, when we talk about mixed regimes created in the post-Soviet space, they are the most unstable, more often than not, changing the trajectory of their development (and, in most cases, not turning toward democracy) $»^{5}$, problems of typology, for example, one country can absorb several types of mixed political regime. In particular, the researchers identified the types of political regime that combined the features of the mixed one. For example, A. Scheedler classified Malaysian political regime as «electoral authoritarianism», L. Morlin as «quasi-democracy», M. Ottawa - «semi-authoritarianism», L. Wei and S. Levitsky as «rivals». On the basis of the above-mentioned meaningful opinion, I consider the opinion of a German scholar, M. Bogar, who in his writings investigated the consequences of the political transformations of the Third Wave and noted, the fact that the presence of numerous definitions of subtypes of democracy and authoritarianism, the absence of common criteria and features that would clearly identify the features of a «mixed» political regime are fundamental to the study of empirical issues ${ }^{6}$.

It should be noted that V. Merkel and A. Croissant can be considered as the first of the scientists to develop a holistic theory and methodological approach to analysis in the phenomenon of mixed political regimes.

The authors introduced the concept of «defective democracy» into scientific circulation. They understand it as a system of domination in which the possibility of access to power is regulated by a powerful and existing universal «electoral regime» (free, secret, equal, and universal elections), but at the same time, there are no other guarantees of basic political and public rights and freedoms, and the horizontal power, control and effectiveness of the democratically legitimate power are severely limited ${ }^{7}$. Particular attention is paid by V. Merkel and A. Croissant to the fact that in defective democracies informal rules (clientelism, personalism, corruption, or cartels, and actors that emerge beyond constitutional boundaries), limit the algorithm for the functionalization of formal, democratically legitimate legitimate factors. They violate the functional codes of formal institutions, deform or

${ }^{5}$ Ремізов А. Гібридний політичний режим: деякі проблеми концептуалізації. Освіта регіону. 2012. № 3. URL: http://social-science.com.ua/article/848

${ }^{6}$ Gagne J.-F. Against Tide? Are Hybrid Regimes more than Sand Castles?. URL: http://papers.ssrn.com/ sol3/papers.cfm?abstract id=1642387.

7 Ремізов А. Гібридний політичний режим: деякі проблеми концептуалізації. Освіта регіону. 2012. № 3. URL: http://social-science.com.ua/article/848. . Brown N., Kauffman C. Introduction. Dynamics of Democratization: Dictatorship, Development, and Diffusion. Johns Hopkins University Press, 2011. P. 1-15. 
replace them as meaningful procedures and decision-making practices. «As a result, at the level of decision-making, democracy functions in accordance with unlawful informal institutions and rules that run counter to the principles of legal democracy» ${ }^{8}$.

V. Merkel cites five criteria that define «defective» democracy: elections, political freedoms, civil rights, horizontal accountability and effects beyond the right to govern'. Accordingly, V. Merkel identifies four subtypes of «defective democracy»: 1) «exclusionary democracy» - which is characterized by all five criteria distinguished by the authors, namely: violation of suffrage by race, ethnicity, gender, polity, gender, sex or gender; 2) «illiberal democracy» - a character that is eroded by the absence of clear boundaries between the executive and the legislative branches, and the judiciary does not, in turn, restrict the first two; 3) »delegative democracy»the legislature and the judiciary exercise limited control over the executive branch, while the constitution is almost not respected by the government in its actions; 4) »guardian democracy» - characterizes the existence of socalled «veto groups» (for example, military movements, international actors), which deprive democratically elected political representatives of the peoples of the political community in access ${ }^{10}$.

Although V. Merkel pays attention to the interconnectedness and importance of every aspect of liberal democracy, the elective indicator of performance is still a function of primus inter pares between "partial regimes». Therefore, first, the emphasis is placed on popular sovereignty as the basis of democracy, secondly, a baseline and criterion is defined for distinguishing democracies from autocracies - countries with no real choices are considered autocritical and are not included in the typology of their democracies.

At the same time, J. Muller and S.-E. Skaaning criticizes some of the propositions of V. Merkel's theory, namely, how to distinguish defective democracies from autocracies, because in their empirical work, researchers have based on the section ad hoc), and not in the dynamics of these regime changes; the correspondence between the "partial regimes» and the subtypes was not perfect, as only four subtypes and defective democracies were constructed as a result of the identification of the five «partial regimes»; the construction of one of the subtypes, namely «exclusionary democracy», does

${ }^{8}$ Ремізов А. Гібридний політичний режим: деякі проблеми концептуалізації. Освіта регіону. 2012. № 3. URL: http://social-science.com.ua/article/848

${ }^{9}$ Меркель В., Круассан А. Формальные и неформальные институты в дефектных демократиях (II). Полис. 2002. № 2. С. 20-30.

${ }_{10}$ Меркель В., Круассан А. Формальные и неформальные институты в дефектных демократиях (I). Полис. 2002. № 1. С. 6-17 
not meet the basic definition of defective democracy as a system and domination in which access to power is governed by its «meaningful» regime; some subcomponents are combined with more than one «partial regime», such as the right to political participation and an independent judiciary $^{11}$.

Also, another point of criticism, but already from another Western researcher - M. Bohaard - is the statement that, that for V. Merkel and A. Croissant there is only one major indicator - democracy, and no other factor is considered - authoritarianism. The German researcher proposes to integrate these two concepts - the defective democracy and the electoral authoritarianism (which is the same «reduced» type of authoritarianism) into one, «two-rooted», for the sake of their variegated regimes ${ }^{12}$. In our opinion, you can agree with M. Bogaards's proposal. Indeed, since any real political regime is composed of many components, the likelihood of combining these components in such combinations when the elements of democratic institutions and processes are combined, explicitly or implicitly, within a single country with certain authoritarian elements. Moreover, the social tradition or habit of the population may even legitimize some authoritarian manifestations of a formally democratic political regime, such as, for example, under General De Gaulle's presidency in France. One can argue about the sources of authoritarian tendencies in the last years of his presidency, but there is undoubtedly the presence in this regime of just such a combination of defective democracy and electoral authoritarianism, as stated by M. Bogaards in his criticism of V. Merkel and A. Croissant.

In this context, a binary typology of the mode offered by the Finnish researcher M. Wiegel is of merit to our attention. Taking the two most important and, according to the scientist, fundamental ideas of democracy the principles of «electoralism» and «constitutionalism» ${ }^{13}$.

All these attributes form a sort of «checklist» for classifying political regimes, following or «comparing» the availability of particular attributes, M. Wiegel identifies four main types of political regimes: authorial, electoral, autocratic, constitutional, oligarchic, and democratic. An

${ }^{11}$ Меркель В., Круассан А. Формальные и неформальные институты в дефектных демократиях (II). Полис. 2002. № 2. С. 23.

${ }^{12}$ Merkel W. Embedded and Defective Democracies. Democratization. 2004. - Vol. 11. Issue 5. P. 33-58

13 . Ремізов А. Гібридний політичний режим: деякі проблеми концептуалізації. Освіта регіону. 2012. № 3. URL: http://social-science.com.ua/article/848. 
analogous «checklist» of Finnish scientists was also built to distinguish mixed political regimes in the model ${ }^{14}$.

Among these, M. Wiegel included «electoral,» «limited,» and «constitutional» democracies. According to the opinion of the researcher, such a two-dimensional typology permits significant comparisons of political regimes and their qualitative and ethical characteristics to be significantly improved from the analytical point of view, since, unlike the one or more, more or less ${ }^{15}$.

Interesting is the variant of typology of the non-critical regimes, proposed by the Danish scientists I. Muller and S.-E. Scaaning.

As a basis for their typology, researchers have taken the following three attributes of a democratic regime: the electoral kernel (free elections) described by J. Schumpeter, the concept of political rights developed by R. Dahl (voting rights, assembly, organizations), and the rule of law, which was justified as a necessary condition of democracy in his writings by G. O'Donnell. Moreover, the researchers emphasize that the well-known Schumper minimalism definition of democracy as a means of gaining power by competing for the electoral votes is more minimal in fact than generally accepted. J. Schumpet's definition is based on general nature of elections (which in this case are «exclusive» - «exclusive elections»), but not at all in their free and deliberate nature (such elections are «inclusive» - «inclusive elections») ${ }^{16}$.

F. Schmitter and G. O'Donnell put forward the concept of «mixed» political regimes and their varieties, which these scholars proposed to call such neologisms, such as dictatorship and democracy ${ }^{17}$. So did S. Huntington, who, analyzing the first results of political transformations in the post-Soviet countries, noted, that a common trend in the development of «third wave democracies» is to turn them into something different from the fullness of democratic regimes. According to him: «We are witnessing the emergence of an increasing number of countries that are somewhere between Denmark and China on the scale of «democracy - not democracy».

${ }^{14}$ Wigell M. Mapping «Hybrid Regimes»: Regime Types and Concepts in Comparative Politics. Democratization. 2008. Vol. 15. №. 2. P. 230-250

${ }^{15}$ Muller J., Skaaning S.-E. Beyond Radial Delusion: Conceptualizing and Measuring Democracy and Non-democracy. International Political Science Review. 2010. Vol. 31. №. 3. P. 261-283.

${ }^{16}$ Bogaards M. How to classify hybrid regimes? Defective democracy and electoral authoritarianism. Democratization. 2009. Vol. 16. Issue 2. P. 399-423

${ }^{17}$ O’Donnell G., Schmitter P. Defining Some Concepts (and Exposing Some Assumptions). Transitions from Authoritarian Rule. Prospects for Democracy / ed. by G. O'Donnell, Ph. C. Schmitter, L. Whitehead. Baltimore, 1986. Vol. 4. P. 9-13 
The essence of the phenomenon of the political regime has forced scholars to return to the question of definition. The first, minimal definition, formulated by J. Schumpeter and subsequently adopted by S. Huntington and other scholars, is based on electoral competitiveness as the essence of those democracies. These conceptions of minimalist democracy, which L. Diamond defines as «electoral democracies,» acknowledge the need for a set of civil liberties that are necessary for competitiveness and participation. At the same time, they do not pay attention to the basic freedoms anticipated and do not seek to include them in the list of valid democracy criteria.

L. Diamond points out that the peculiarity of post-Soviet society is the intermediate position, which does not allow it to be correlated with either liberal democracy or electoral democracy. To understand the dynamics of regime change and the process of democracy development in the context of the «third wave», in which the Ukrainian transformation process takes place, an American scientist considers it necessary to allow the existence of a third category of regimes that do not correlate even with minimalist democracy, but at the same time defines as «pseudodemocracy». These regimes may meet the high demands of constitutional characteristics of «electoral democracy»; they are legally operated by opposition parties; however, they are deprived of such essential democratic qualities as the existence of a field for relatively electoral rivalry capable of leading to the removal from power of the ruling party. L. Daimon believes that many post-Soviet countries, such as Russia or Kazakhstan, in which quasi-institutionalized systems of power were formed, serve as examples of such «pseudo-democracies» ${ }^{18}$.

Thus, in analyzing and post-Soviet political regimes, L. Diamond recommends using a typology, which uses three classifiers. This typology presupposes an account of the evolutionary character of the democracy and should capture intermediate stages within the process. "Pseudodemocracy» is a regime that has made minimal progress from authoritarianism. A more advanced stage is «electoral democracy». Finally, the consolidation of democracy, which means the expansion of mass civil liberties and the assimilation of democratic values at the level of political culture and population, permits the democratization of the regime.

In political science, one of the most widely deployed and substantiated concepts of the essence of the transitional regime can be recognized as the theory of «mixed mode», which was proposed by L.F. Shevtsov ${ }^{19}$.

${ }^{18}$ Levitsky S., Way L. The Rise of Competitive Authoritarianism. Journal of Democracy. 2002. Vol. 13. № 2. P. 51-65.

${ }^{19}$ Шевцова Л. Ф. Режим Бориса Ельцина. М. : Московский Центр Карнеги, 1999. 535 с. 
Investigating the problems of transitional regimes typology, L.F. Shevtsova notes that the experience of some countries of the postSoviet space does not allow them to be fully attributed to the classification already developed. Among them, the most similar to the post-Soviet regimes are the types of «delegated democracy» and «bureaucratic-authoritarian states» developed by G. O'Donnell on the example of Latin American countries $^{20}$. However, the author notes, along with a number of similar characteristics, transitional regimes in countries of the former USSR that have special features.

The concept of «competitive authoritarianism» has received considerable recognition among scholars and was developed by American political logos S. Levitsky and L. Weyem, who were among the first to call for the use of different categories from the category of «democracies with adjectives» to the movement towards democracy. In this case, definitions such as «delegative democracy», "semi-democracy», «virtual democracy», «electoral democracy», «illiberal democracy» and many others are misleading as to the true direction, trajectories, which are obviously not moving in the direction of democracy ${ }^{21}$.

Under the conditions of competitive authoritarianism, basic democratic institutions are functioning, but the abuse of power by the opposition entails that the normative functions of these institutions are deformed.

At the same time, competitive authoritarianism is strikingly different from the traditional authoritarian regime. Unlike pure authoritarianism, in the face of competitive authoritarianism, the opposition maintains some spaces of freedom for its activities. If full-scale authoritarianism overtly and brutally crushes the opposition, then under competitive authoritarianism, the government acts more sophisticatedly, limiting its administrative measures through fiscal, judicial, and other oversight services.

\section{Current trends of deformation of democratic regimes}

As the experience of developed countries shows, there are serious problems in democracy, the solution of which is a prerequisite for its effective functioning. J. Bechler calls these problems «distortions of democracies», N. Bobbio - «unfulfilled promises of democracy», F. Schmitter - «threats of democracy», and S. Eisenstadt - «fragility of modern democratic regimes».

\footnotetext{
${ }^{20}$ Шевцова Л. Ф. Режим Бориса Ельцина. М. : Московский Центр Карнеги, 1999. С. 508.

${ }^{21}$ Levitsky S., Way L. The Rise of Competitive Authoritarianism. Journal of Democracy. 2002. Vol. 13. № 2. P. 52.
} 
Many states in South America, Eastern Europe and Asia, according to F. Schmitter, will not be able to establish a form of stable self-government appropriate to their social structures or acceptable to citizens. Democracy never transforms itself into a specific, reliable and generally accepted set of rules $^{22}$. A particular state chooses its type of democracy by resolving dilemmas related to its own history, geostrategic position, natural and human resources. F. Schmitter identifies the internal dilemmas inherent in modern democracy, regardless of place and time of its emergence, and external ones, which call into question the compatibility of new democratic rules and practices with existing social, cultural and economic conditions ${ }^{23}$.

Scientists include internal problems, first of all, oligarchy, selfelimination, «cyclicality in politics», functional autonomy, interdependence of national leaders from other democracies and some autocracies ${ }^{24}$.

External dilemmas are determined by the collective choice between alternative institutional arrangements compatible with existing socioeconomic structures and cultural realities.

According to F. Schmitter, only knowledge of the habits brought up by the experience of democracy in the country, and only the location of actors within the appropriate methods of transition allow to give a correct assessment of the most adequate use of the institutions of power. History shows that not all countries have ever been able to consolidate democracy on the first attempt.

From the point of view of F. Schmitter, there are at least two other options for development in countries that have embarked on the path of democratic transformation: the creation of a hybrid regime that combines elements of autocracy and democracy, which is endowed with the signs of unconsolidated democracy ${ }^{25}$.

In cases where the transition period is initiated and imposed from above, the former rulers try to protect their interests by «grafting» authoritarian practices. In the cases where they carry out liberalization without democratization (that is, when certain individual rights are allowed without citizenship consent), leading to the emergence of a hybrid regime, this form of government is called by F. Schmitter dictablanda. In the same cases when

22 Шмиттер Ф. К. Угрозы и дилеммы демократии. Русский журнал. URL: [http://www.russ.ru/antolog/predely/1/dem2-2.htm.

23 Шмиттер Ф. К. Угрозы и дилеммы демократии. Русский журнал. URL: [http://www.russ.ru/antolog/predely/1/dem2-2.htm.

24 Роберт Міхельс і його «залізний закон олігархії». URL: http://yuriyshveda.com.ua/de/communication/teoria-politichnih-partiy/484-michels.html

25 Шмиттер Ф. К. Угрозы и дилеммы демократии. Русский журнал. URL: [http://www.russ.ru/antolog/predely/1/dem2-2.htm. 
the political elite conducts democratization without liberalization (that is, when elections are held, but in the conditions of guaranteed victory of the ruling party, exclusion of certain socio-political groups from participation in them, or deprivation of elected citizens of real government) neologism «democradura» was proposed.

Both dictablanda and democradura have become quite commonplace as authoritarian rulers seek to introduce democratic mechanisms in their states to make visible the progressive transformations of international forces that require democratization.

Threats to democracy in post-socialist countries have been studied by many researchers. S. Huntington believes that barriers to democratization can be divided into three broad categories: political, cultural and economic ${ }^{26}$.

Klaus Offe reasonably noted that «the legal and representative political system will become adequate and will restore legitimacy only when a degree of autonomous economic development has already been achieved ${ }^{27}$.

The problem is compounded by the fact that the political culture of authoritarian egalitarianism, shared by the majority of the citizens of these countries, does not envisage either a market economy or democracy as reform goals.

Robert Dahl points to inequality as a fundamental problem in all democracies. The perspective of democracy development, in its view, depends on the degree of approach of the demos (people) to the decisionmaking elite. The improvement of citizens, their active participation in the life of society and the state is a prerequisite for the development of democracy. And the higher the level of political participation, the closer the citizens are to the ever-increasing level of demands on the participants in the political process, the closer democracy is to its ideal, which one can and should strive for, but which cannot be achieved ${ }^{28}$.

Democracy threats can also come from both the masses and the elite. Analyzing the behavior of the masses in the context of American democracy, Peter Bahrach wrote: «The widespread commitment of society to the fundamental norms that underpin the democratic process has been regarded by theorists of classical democracy as an integral element of the survival of democracy. ... Today, however, sociologists tend to reject this view. They came to this conclusion not only because of doubts about the commitment of

${ }^{26}$ Хантингтон С. Третья волна. Демократизация в конце XX века / пер. с англ. М.: РОССПЭ, 2003. С. 338.

27 Оффе К. Культурные аспекты консолидации: заметки об особенностях посткоммунистической трансформации. Восточноевропейское обозрение. 1998. № 1. С. 11.

${ }^{28}$ O'Donell G., Schmitter P. Transitions from Authoritarian Rule: Tentative Conclusions about Uncertain Democracies. Baltimore, Md : Johns Hopkins University Press, 1986. 280 p 
«non-elites» to freedom, but also because there is a growing conviction that «non-elites» are mostly inspired by political elites. The empirical conclusion that the behavior of the masses is usually a reaction to the position, proposals and actions of political elites, further confirms the view that the responsibility for maintaining the «rules of the game» rests with the shoulders of the elites, not the people» ${ }^{22}$.

However, while elites more than the masses are committed to the values of democracy, they often abandon those values in times of crisis and resort to repression. The activism of the masses and the repression of the elites are often combined, creating numerous threats to democracy. The activity of the masses, which is manifested in riots, demonstrations, extremism, violence, arouses fear and danger in the elites who respond to restrictions on will and increased security measures. At the same time, dissent is questioned, the press is censored, freedom of speech is restricted, representatives of potential counter-insiders are imprisoned, and police and security forces are being strengthened in the name of «national security» or «law and order».

The elites are convincing themselves that these steps are necessary to preserve liberal democratic values. T. Dai and L. Ziegler point out: «The irony is that by trying to preserve democracy, the elites are turning society into a less democratic one» ${ }^{30}$.

E. Eisenstadt believes that the constitutional-democratic regimes are fraught with fragility and instability, the origins of which are determined not by specific causes that can cause instability in any social structure or political system, but rooted in the ideological and institutional history of modern political institutions, in the cultural and political agenda of today. Israeli political scientist believes that the basis for such allegations is the openness of the political process in constitutional democracies and the tendency to re-evaluate constantly the political sphere. «This openness,» writes Schnitz Eisenstadt, «is the main reason for the fragility of modern democratic regimes, but the paradox is that it ensures the continuity of their existence ${ }^{31}$. The openness of political systems testifies to their ability to adapt to the changing reality, the perception of the necessary changes, which leads, in the words of Eisenstadt, to the formation of the idea of politics as a «game» with zero amount, when winning one side is not equivalent to losing the other.

29 Оффе К. Культурные аспекты консолидации: заметки об особенностях посткоммунистической трансформации. Восточноевропейское обозрение. 1998. № 1. С. 8.

${ }^{30}$ Дай Т. Р., Зиглер Л. Х. Демократия для элиты: Введение в американскую политику. М. : Юрид. лит-ра, 1984. С. 48-49.

31 Эйзенштадт Ш. Н. Парадокс демократических режимов: хрупкость и изменяемость (I). Полис. 2002. № 2. С. 67. 
J. Bechler explains the "deficit of democracy» by inevitably hostile circumstances. First of all, it is an economic cycle that does not remain in a stable state for a long time, which negatively affects the realization of promises coming from the government to the citizens. An even more hostile circumstance for democracy is social stratification. In an ideal democracy, the distribution, according to the majority of researchers, should not be equal, but fair. Everyone receives their share of power, wealth, prestige in accordance with their competence, contribution to common wealth and their merit. The mobility of the individual, both vertical and horizontal, should be high, which should lead to the creation of ever changing, weakly expressed hierarchies.

However, the reality is far from a democratic ideal, which is explained by the benefits that proximity to power brings to the next generation. This leads to the fact that power, prestige and wealth depend to a large extent on the social layer to which this or that individual belongs. As a result, competence, contribution to the common cause, natural gifts and personal merit can be humiliated and deprived of their legal rights by holders of a position inherited and preserved in the face of democratic justice. The resulting social stratification causes protests against inequality in a democratic society.

As noted, J. Bechler distinguishes three types of distortions of democracy - political, ideological and moral ${ }^{32}$. By political distortions, he understands the political market, which means exchange, distribution, and search. Exchanges occur between the private and public spheres. Private interests act as one of the parties to the exchange and offer their votes and assistance to the partner during the election. Their partners are politicians who need votes and the support of citizens for election to the authorities. This is where the conflict with democracy arises. Since democracy is the the desire in the common affairs for the common good, there is a conflict of interest between the private and the public. The distortion of democracy is all the more explicit here, the more actively the private interests are implemented, which entails the opposite process - the suppression of private interests by the public sphere ${ }^{33}$. Distortion is exposed to the activities of politicians who send their activities not for the common good, trying to convince citizens of their interpretation of the common good and authority in the search for the right goal. The bottom line is that the political market legitimizes dishonesty.

${ }^{32}$ Бешлер Ж. Демократия. Аналитический очерк / пер. с фр. М. : изд-во «Памятники исторической мысли» 1994. 208 с.

${ }^{33}$ Бешлер Ж. Демократия. Аналитический очерк / пер. с фр. М. : изд-во «Памятники исторической мысли» 1994. 208 с. 
Ideological distortions arise from the fact that every principle of democracy can be misinterpreted, and any false interpretation can lead to ideological conclusions that are dangerous to democracy if they are put into practice. J. Bechler dwells on the two most common principles. One of them is the sovereignty of the people. People are abstractions. It is a team that is always silent, possessing neither the will nor the capacity to act. To declare that power belongs to the people means to create a real danger of replacement of the people by its representatives who consider themselves legitimate bearers of power. And since the people are silent and decide nothing, then these representatives become holders of unlimited power, which leads to the emergence of autocratic regimes.

Another ideological distortion is the belief that democracy is the rule of the majority. J. Bechler believes that it is certainly valid for the public sphere, and that there are distortions in the sphere of private interests. So, instead of generating middle interests through a regulated market as a result of free trade, people prefer to organize a general meeting at which a majority, whose interests are imposed by others, is revealed by voting. According to the French political scientist, such a procedure is unlawful and illegal in a democratic society; moreover, it allows manipulation by organized groups and is an excuse for the oppression of minorities. Completed to its logical conclusion, the majority rule leads to autocracy ${ }^{34}$.

Moral distortions include all abuses of liberty that are facilitated by the guarantee of public liberties, the separation of public and private spheres and the principle of political legitimacy of all opinions. The scientist focuses on the differences of people in their adaptation to the surrounding living conditions. The strongest, the minority, are able to clearly set goals and strive to achieve them. Most include not the strongest or the weakest, but ordinary people who are able to take care of the problems and be responsible for the results achieved, while the weakest ones, who are also a minority, are unable to solve the problems that arise. They are poorly adapted and do not know how to experience modern individualization on their own and for themselves ${ }^{35}$.

\section{CONCLUSIONS}

Thus, despite these deficits and the distortions of democracy, J. Bechler looks optimistically into the future of democratic development, justifying his optimism that, first, they cannot all exist forever, and second, their gradual filling enhances the stability of democracy. Democratization is stretching over time, which in an unexpected way contributes to stability. Modern

\footnotetext{
${ }^{34}$ Бешлер Ж. Демократия. Аналитический очерк / пер. с фр. М. : изд-во «Памятники исторической мысли» 1994. 208 с.

${ }^{35}$ Бжезинський 3. Великі перетворення. Політична думка. 1994. № 3. С. 5-14.
} 
democratic institutions and practices are capable of peacefully resolving problems between the authorities and society by changing the team in power in a fair, impartial election.

In order for democratic development to become a reality, citizens must have a sufficient stock of patience and optimism, as they are forced to adapt quickly to the new situation and wait long enough for the positive results of reforms.

Despite all the difficulties that democracy has to face on its thorny path, we are living in a democratic era. For a long time, the danger of human life, liberty and happiness came from the absolutism of monarchies, the dogmatism of churches, the terror of dictatorships and totalitarian leaders. Dictators and some totalitarian regimes still exist, but they are becoming increasingly anachronistic in the modern world. There is no longer a decent alternative to democracy, it represents, in the words of American political scientist F. Zacharya, «part of the present» ${ }^{36}$.

Thus, in the twenty-first century, problems of government are likely to be problems within democracy itself. This complicates their decision as they dress in the mantle of legality.

\section{SUMMARY}

It is established that there is no single and comprehensive classification of hybrid regimes among scientists. However, an analysis of the existing attempts at typologizing allows us to distinguish the electorally-autocratic and constitutionally-oligarchic type of hybrid regime. The criteria for distinguishing between types of hybrid regimes include the level of compliance with the principles of «electoralism» and «constitutionalism». The main tendencies of deformation of democratic regimes in emerging countries and sustainable democracies are revealed. These include the socalled «distortions of democracy», "unfulfilled promises of democracy», «threats to democracy» and «the fragility of modern democratic regimes».

\section{REFERENCES}

1. Бешлер Ж. Демократия. Аналитический очерк / пер. с фр. М. : изд-во «Памятники исторической мысли» 1994. 208 с.

2. Бжезинський 3. Великі перетворення. Політична думка. 1994. № 3. С. 5-14.

3. Дай Т. Р., Зиглер Л. Х. Демократия для элиты: Введение в американскую политику. М. : Юрид. лит-ра, 1984. 320 с.

36 Закария Ф. Возникновение нелиберальных демократий. Логос. 2004. № 2 (42). C. $55-70$ 
4. Закария Ф. Возникновение нелиберальных демократий. Логос. 2004. № 2 (42). C. 55-70.

5. Клямкин И. М. Что значит быть демократом сегодня?: логика реформации тоталитаризма (круглый стол). Полис. 1991. № 4. С. 47-51.

6. Меркель В., Круассан А. Формальные и неформальные институты в дефектных демократиях (I). Полис. 2002. № 1. С. 6-17.

7. Меркель В., Круассан А. Формальные и неформальные институты в дефектных демократиях (II). Полис. 2002. № 2. С. 20-30.

8. Оффе К. Культурные аспекты консолидации: заметки об особенностях посткоммунистической трансформации. Восточноевропейское обозрение. 1998. № 1. С. 8-10.

9. Ремізов А. Гібридний політичний режим: деякі проблеми концептуалізації. Освіта регіону. 2012. № 3. URL: http://socialscience.com.ua/article/848.

10. Роберт Міхельс і його «залізний закон олігархії». URL: http://yuriy-shveda.com.ua/de/communication/teoria-politichnih-partiy/484michels.html

11. Хантингтон С. Третья волна. Демократизация в конце XX века / пер. с англ. М.: РОССПЭ, 2003. 368 с.

12. Шевцова Л. Ф. Режим Бориса Ельцина. М. : Московский Центр Карнеги, 1999. 535 с.

13. Шмиттер Ф. К. Угрозы и дилеммы демократии. Русский журнал. URL: [http://www.russ.ru/antolog/predely/1/dem2-2.htm.

14. Эйзенштадт Ш. Н. Парадокс демократических режимов: хрупкость и изменяемость (I). Полис. 2002. № 2. С. 67-82.

15. Analytical briefs. Freedom House. URL: https://freedomhouse.org/ report-types/nations-transit.

16. Bogaards M. How to classify hybrid regimes? Defective democracy and electoral authoritarianism. Democratization. 2009. Vol. 16. Issue 2. P. 399-423.

17. Brown N., Kauffman C. Introduction. Dynamics of Democratization: Dictatorship, Development, and Diffusion. Johns Hopkins University Press, 2011. P. 1-15.

18. Collier D., Levitsky S. Democracy with Adjectives: Conceptual Innovation in Comparative Research. World Politics. 1997. Vol. 49. № 3. P. 430-451.

19. Diamond L. Is Third Wave Over? Journal of Democracy. 1996. Vol.7. № 3. P. 20-37. 
20. Gagne J.-F. Against Tide? Are Hybrid Regimes more than Sand Castles?. URL: http://papers.ssrn.com/ sol3/papers.cfm?abstract id $=1642387$.

21. Levitsky S., Way L. The Rise of Competitive Authoritarianism. Journal of Democracy. 2002. Vol. 13. № 2. P. 51-65.

22. Merkel W. Embedded and Defective Democracies. Democratization. 2004. - Vol. 11. Issue 5. P. 33-58.

23. Muller J., Skaaning S.-E. Beyond Radial Delusion: Conceptualizing and Measuring Democracy and Non-democracy. International Political Science Review. 2010. Vol. 31. №. 3. P. 261-283.

24. O'Donell G., Schmitter P. Transitions from Authoritarian Rule: Tentative Conclusions about Uncertain Democracies. Baltimore, Md : Johns Hopkins University Press, 1986. 280 p.

25. O'Donnell G., Schmitter P. Defining Some Concepts (and Exposing Some Assumptions). Transitions from Authoritarian Rule. Prospects for Democracy / ed. by G. O'Donnell, Ph. C. Schmitter, L. Whitehead. Baltimore, 1986. Vol. 4. P. 9-13.

26. O'Donnel G., Schmitter P. Transitions from authoritarian rule: prospects for democracy.. Baltimore, 1986. $208 \mathrm{p}$.

27. Wigell M. Mapping «Hybrid Regimes»: Regime Types and Concepts in Comparative Politics. Democratization. 2008. Vol. 15. №. 2. P. 230-250.

\section{Information about the author: Dziubenko Yu. M., $\mathrm{PhD}$ in Political Science,} Associate Professor at the Department of Political Theories of the National University «Odesa Law Academy» 2, Academichna str., Odesa, 65009, Ukriane 